\begin{tabular}{|c|c|c|c|c|c|c|c|}
\hline \multirow{3}{*}{ 表 } & \multirow{2}{*}{ Berkala Arkeologi } & \multirow{2}{*}{ (c) (i) (-) } & \multicolumn{5}{|c|}{ Original Version } \\
\hline & & & ISSN & : & 0216-1419 & E-ISSN & $2548-7132$ \\
\hline & Volume 40 No. 2, November 2020, 243-266 & DOI: $\underline{10.30883 / j b a . v 4}$ & 2.552 & & https://berk & aarkeologi.ke & mdikbud.go.id \\
\hline
\end{tabular}

\title{
RECOMMENDATIONS ON CULTURAL HERITAGE SITE MANAGEMENT PLAN FOR THE PUNJULHARJO BOAT IN REMBANG, CENTRAL JAVA
}

\section{REKOMENDASI RANCANGAN PENGELOLAAN SITUS CAGAR BUDAYA PERAHU PUNJULHARJO DI REMBANG, JAWA TENGAH}

\author{
Agni Sesaria Mochtar ${ }^{1}$ \\ Regional Agency for Archaeological Research in D.I. Yogyakarta Province \\ mochtar.agni@gmail.com
}

\begin{abstract}
ABSTRAK
Perahu kayu Punjulharjo adalah salah satu alat transportasi air tradisional yang dibuat dengan teknik tambuku-terikat khas Asia Tenggara. Perahu ini ditemukan pada tahun 2008, kemudian dieksvasi dan setelahnya dibongkar untuk dikonservasi dalam proses yang cukup panjang. Pada awal tahun 2018, kayu-kayu lambung kapal direkonstruksi dan dipamerkan kepada masyarakat. Perahu ini telah ditetapkan sebagai situs cagar budaya berdasarkan Peraturan Menteri Kebudayaan dan Pariwisata No.57 tahun 2010. Akan tetapi, belum ada perencanaan pengelolaan yang dapat menjamin kelestarian situs Perahu Punjulharjo ini. Rekomendasi dalam rancangan pengelolaan ini disusun dengan mengacu pada standar international rencana pengelolaan situs cagar budaya. Data untuk penyusunan rencana pengelolaan ini diperoleh dari pengamatan langsung di situs dan dilengkapi dengan penelusuran referensi terkait. Rencana pengelolaan ini menjabarkan strategi dan langkah-langkah pengelolaan yang perlu diterapkan untuk perlindungan dan pelestarian situs, yang diharapkan dapat digunakan sebagai acuan bagi Pemerintah Daerah Kabupaten Rembang sebagai pengelola situs perahu Punjulharjo.
\end{abstract}

Kata Kunci: Punjulharjo; perahu; pengelolaan; maritim; museum semi-terbuka

\section{ABSTRACT}

The Punjulharjo boat is a wooden watercraft, built in the traditional Southeast Asian boat building technique called lashed-lug tradition. It was found in 2008, excavated, and later was dismantled for a lengthy conservation process. In early 2018, the hull was reassembled to be displayed for public. The site where the boat was found, and now displayed, has been listed as a heritage site under the Regulation of The Minister of Culture and Tourism No. 57 of 2010, but a management plan of it is still non-existent. Recommendations in this proposed management plan was amassed in accordance to international standards on site management plan. Data was collected from direct site observation, with the assistance of consultations to related references. This plan outlines objectives and strategy in managing the Punjulharjo site, and hopefully can serve as guidelines for the Regional Government of the District of Rembang as the manager of the site.

Keywords: Punjulharjo; boat; management; maritime; semi-open museum

Article Submitted : : 23-03-2020

Article Accepted : :29-07-2020 


\section{INTRODUCTION}

The Punjulharjo boat is one of only a few wooden shipwrecks found to date in Indonesia. It was found accidentally, in 2008, after the villagers dug out the sandy soil to make a salt evaporation pond (Abbas, 2013). It is in a coastal area, around a half kilometer south of Rembang's northern coastline in Central Java, Indonesia and just about $300 \mathrm{~m}$ from the main road, Jalan Raya Pantura (Figure 1). The boat was named after the village where it was found, but the locals often refer the boat as "prahu Punjul". During the initial finding, a joint team of heritage agencies excavated the site and uncovered a nearly complete hull, where the bow all the way to the stern of the boat were still intact.

Later on, the team who excavated the boat in 2009 learned that the boat was built in lashed-lug technique (Sulistyarto, 2013, p. 55), a traditional boat building technique commonly used in ancient Southeast Asian islands from around the third to sixteenth century C.E. (Lacsina, 2016, pp. 98-142). The Punjulharjo boat, with only a few planks on the upper strakes missing, is the only lashed-lug vessels that is found with the hull and the internal fastenings still intact, not only in Indonesia but also in Southeast Asia. From radiocarbon dating analysis, the excavation team stated that the boat dated from the seventh century C.E. (Abbas, 2013, p. 42). Therefore, the Punjulharjo boat is the oldest wooden shipwreck found in Java and the second oldest lashed-lugs vessel found in Indonesia to date.

Under the Regulation of the Minister of Culture and Tourism No. 57 of 2010 the location of the Punjulharjo boat was listed as Cultural Conservation Site. Soon after, the boat underwent a lengthy conservation process to especially treat all the organic materials. During this process, the boat was dismantled, and finally reconstructed in early 2018 after the conservation treatment have had finished. However, it is unfortunate that the deterioration of several components of the boat are still visible and beyond repaired. All the conservation process was conducted on site, and the Punjulharjo boat is currently displayed for public in its original finding location.

Due to its relatively remarkable condition, the Punjulharjo boat, along with the Butuan boats in the Philippines and the Cirebon shipwreck, provides a better opportunity to understand the history of the lashed-lug ship/boatbuilding tradition, that is now already extinct. The knowledge derived from these boats would not only be limited to Indonesia, but also in Southeast Asia, and possibly beyond. It is known that the Austronesians had sailed from Taiwan to the Islands of Southeast Asia before departing to as far as Madagascar in the west and the Pacific in the east (Horridge, 1995; Mahdi, 1999). Ancient chronicles mentioned how Indonesia was one of the critical parts of the early international trade between eastern Asia, particularly China, and the western world (Hall, 2011, pp. 42-47). Maritime archaeological findings also confirmed this with several shipwreck sites showed that ships voyaged on Indonesian waters were carrying valuable commodities (Caixia, 2011; Liebner, 2014). The information contains in the boat and therefore the site - can offer additional knowledge on this discussion, how Indonesia had been part of international routes since before the Common Era.

It is clear that the Punjulharjo site holds several important values and significance. However, it is also apparent that the site is facing challenges that could impact its protection and preservation, such as being situated in coastal area 


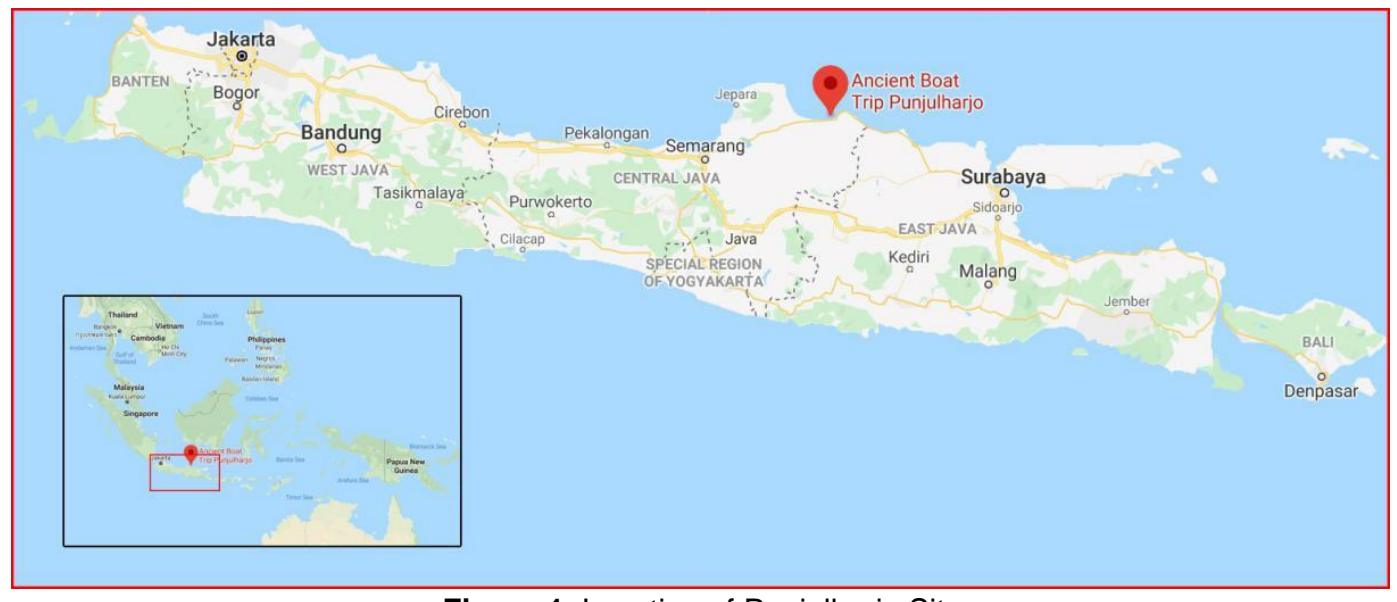

Figure 1. Location of Punjulharjo Site

(Source: Google Image 2020)

with the rather harsh weather, housing heritage object(s) consisted of organic materials and attracting various parties with different interest. It is imperative to formulate a cultural heritage site management plan of the Punjulharjo Site to strive for a long-term protection and preservation of the site. Recommendations in this management plan outlines most of the principles of the standards management strategy (see: ICOMOS, 2017; Natural England, 2008) applicable for the Punjulharjo Site. It contains assessment of the condition of the boat's remains and the surrounding's environment. It will also discuss the significance of the site and the threats that might impact them. The plan also discusses legislative context of the protection of the site and will outline a series of action to implement the management strategy, which includes a conservation and development plan, as well as a monitoring system of the site.

\section{METHODS}

This study is an applied archaeological research; a stream in the discipline where archaeological research addresses modern issues concerning cultural heritage, such as (but not limited to) cultural heritage management, community engagement on cultural heritage, and heritage tourism (Perring, 2008, p. 19). For this particular study, data from archaeological research was applied as one of the phases of formulating a cultural heritage management plan. Whereas the outline is not in a full report scheme, the recommendations were formulated in accordance to manuals and guidelines recognized internationally and covered the principles of cultural heritage management plan elaborated in said standards. Data was used to design an applicable management plan, one that hopefully can be referred by heritage conservation and/or management agencies, especially the Government of the District of Rembang as the lead organization of managing the Punjulharjo Site.

According to UNESCO's Managing World Cultural Heritage (2013, p. 123), a management plan is

"the guidance document developed within, and describing, a particular management system. It is an important tool for all phases of the management cycle (planning, 
implementation, monitoring) at a cultural heritage property and needs to be periodically reviewed and renewed".

It provides a clear description of the condition of the site, along with its current condition, an assessment of the site's significances and value, and some factors that might impact the preservation of the site. A cultural heritage management plan should provide strategy and a series of action to ensure long-term protection of cultural heritage site. It needs also to address stakeholder's involvement in managing a site (UNESCO et al., 2013, pp. 124-125).

The cultural heritage site management plan for the Punjulharjo boat was designed based on data collected from both survey on the site and literatures review. The author visited the boat from late 2017 to early 2018, during the last phase of conservation work and the reconstruction of the hull timbers into the current display. The observation allowed the author to document detailed components of the boat while it was being dismantled, and to record the deterioration stage of the timbers. The following year, secondary data from literatures, statutes, and other references were consulted to gain information about legislative context as well as standard procedure of heritage conservation.

In addition, the author also maintained personal communication with the conservator from Agency for Borobudur Conservation (Balai Konservasi Borobudur), the Head of History, Museum, and Archaeology Section of the Government of the District of Rembang, and the staff of Directorate of Cultural Protection (Direktorat Perlindungan Kebudayaan/Dit. PK) - formerly Directorate of Culture Pledge Conservation and Museology/ Dit. PCBM - since the completion of the fieldwork until the writing of this management plan. The consultations covered the conservation process conducted on site and the development plan of the site to ensure that this management plan is consistent and up to the latest development of the Punjulharjo Site.

\section{RESEARCH RESULTS}

The Punjulharjo Site is located in an open area, surrounded by salt evaporation ponds on the north, yards on the west and south, and local houses a bit further on the east (Figure 2). The main access to this site is a single-car road, which is connected to the main road, Jalan Raya Pantura, around three hundred meters south of the site. Less than a kilometer northeast of the site, there is a renowned tourist attraction called the Karangjahe Beach. During holiday seasons, many people visit the site after they enjoy the beach. 


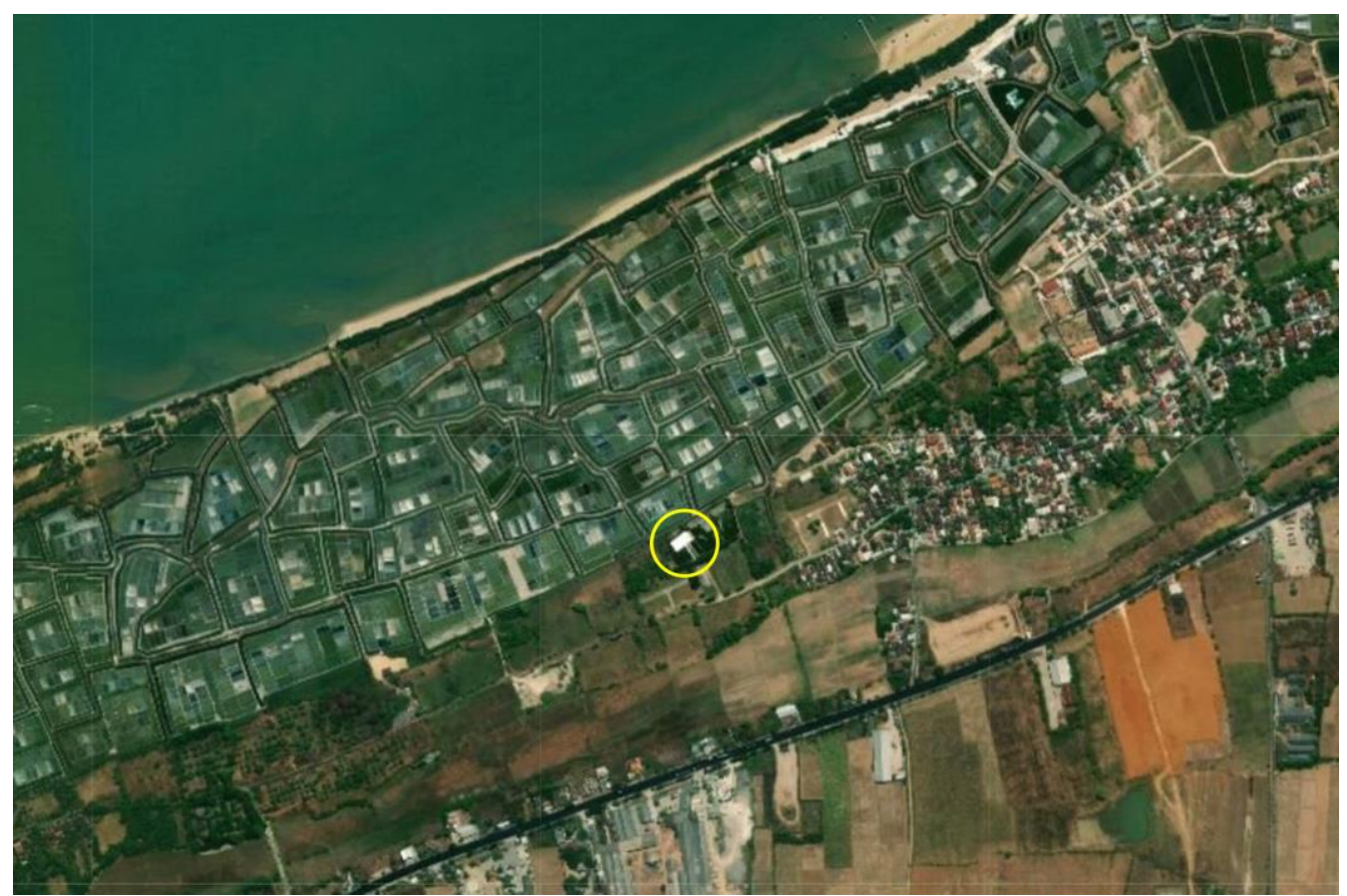

Figure 2. The Location of Punjulharjo Site (yellow circle) From the Coastline and the Main Road (Source: ESRI World Imagery 2020)

\section{Historical Background}

In July 2008, local people accidentally unearthed the boat when they made salt evaporation ponds (Figure 3). The local village authorities then reported this finding to the heritage agencies. Soon after, a collaborative team from Regional Agency for Archaeological Research in D.I. Yogyakarta Province (Balai Arkeologi Provinsi Daerah Istimewa Yogyakarta/ Balar Prov. DIY) - or Balai Arkeologi Yogyakarta then - and Regional Office for Cultural Properties Preservation in Central Java Province (Balai Pelestarian Cagar Budaya Jawa Tengah/ BPCB Jawa Tengah) visited the site to perform an immediate excavation to study the significance of the findings (Abbas, 2013). Considering the hot coastal weather on the site, a semi-permanent shelter was later built to protect the boat from the heat (Figure 4). The only access to the site, however, was still through paths between the salt ponds.

Five months later, Balar Prov. DIY had another visit to the site. They brought Prof. Manguin - an expert in Southeast Asian maritime archaeology with them to identify the boat. He concluded that the Punjulharjo boat was built with the lashed-lugs technique, a traditional boatbuilding method native in Southeast Asia. Two pieces of evidence to support his conclusion were the protruding lugs on the interior of the hull and the frames that were fastened on to the hull using lashing ropes (Manguin, 2009). Prof. Manguin took rope samples to be radiocarbon-dated to avoid the old-wood syndrome that might come up from dating the timbers. Later, this dating revealed the age of the boat to be 660-780 C.E. (Abbas, 2013, p. 42). 


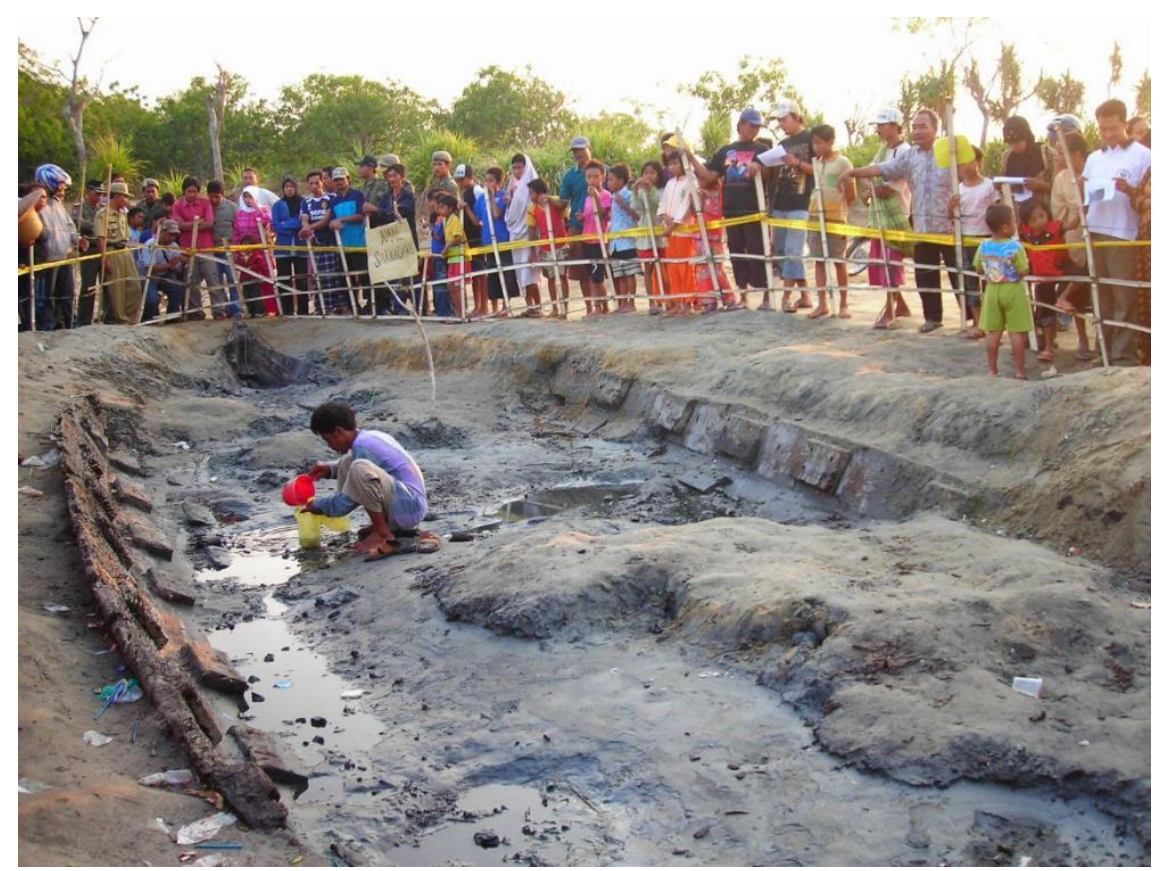

Figure 3. Punjulharjo Boat When It Was First Found in 2008

(Source: Balar Prov. DIY)

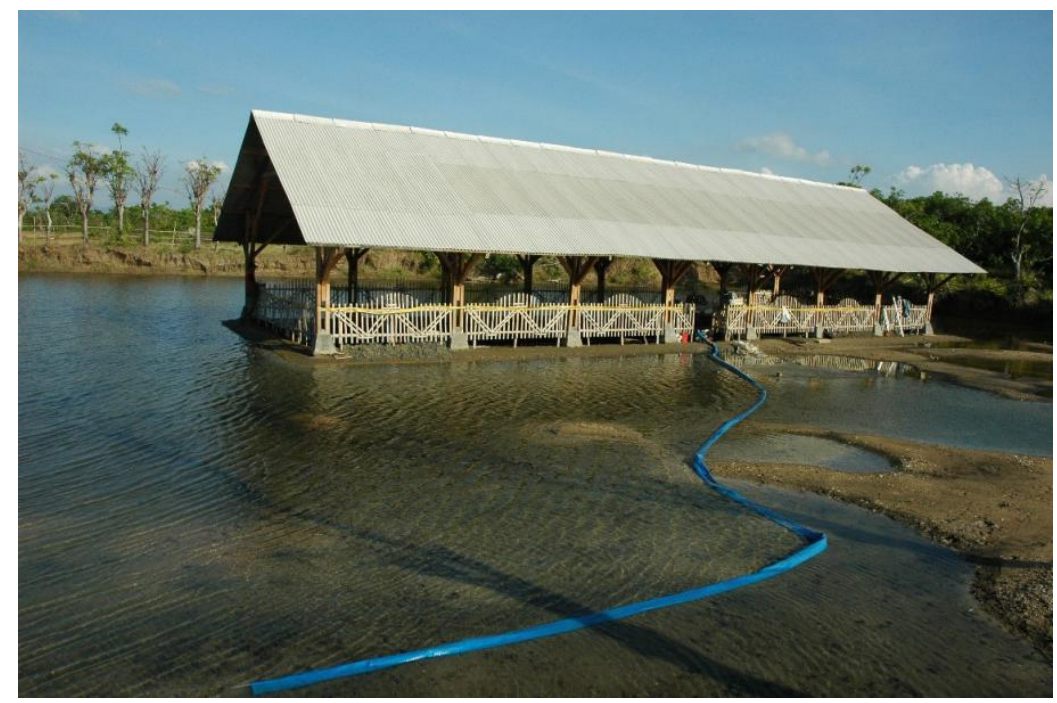

Figure 4. The Shelter to Cover The Site, Built in 2008

(Source: Balar Prov. DIY)

In the following year, the same institution conducted another excavation to obtain more comprehensive insights into the Punjulharjo boat. This project aimed to reveal the rest of the boat (Figure 5) to understand its construction and the technology used to build it. After the excavation was deemed sufficient, they officially handed over the site to BPCB Jawa Tengah to be looked after. BPCB Jawa Tengah started to manage the site to be more presentable and accessible for the public. They built pavement to the location of the boat and put up signs to provide direction to the site. 


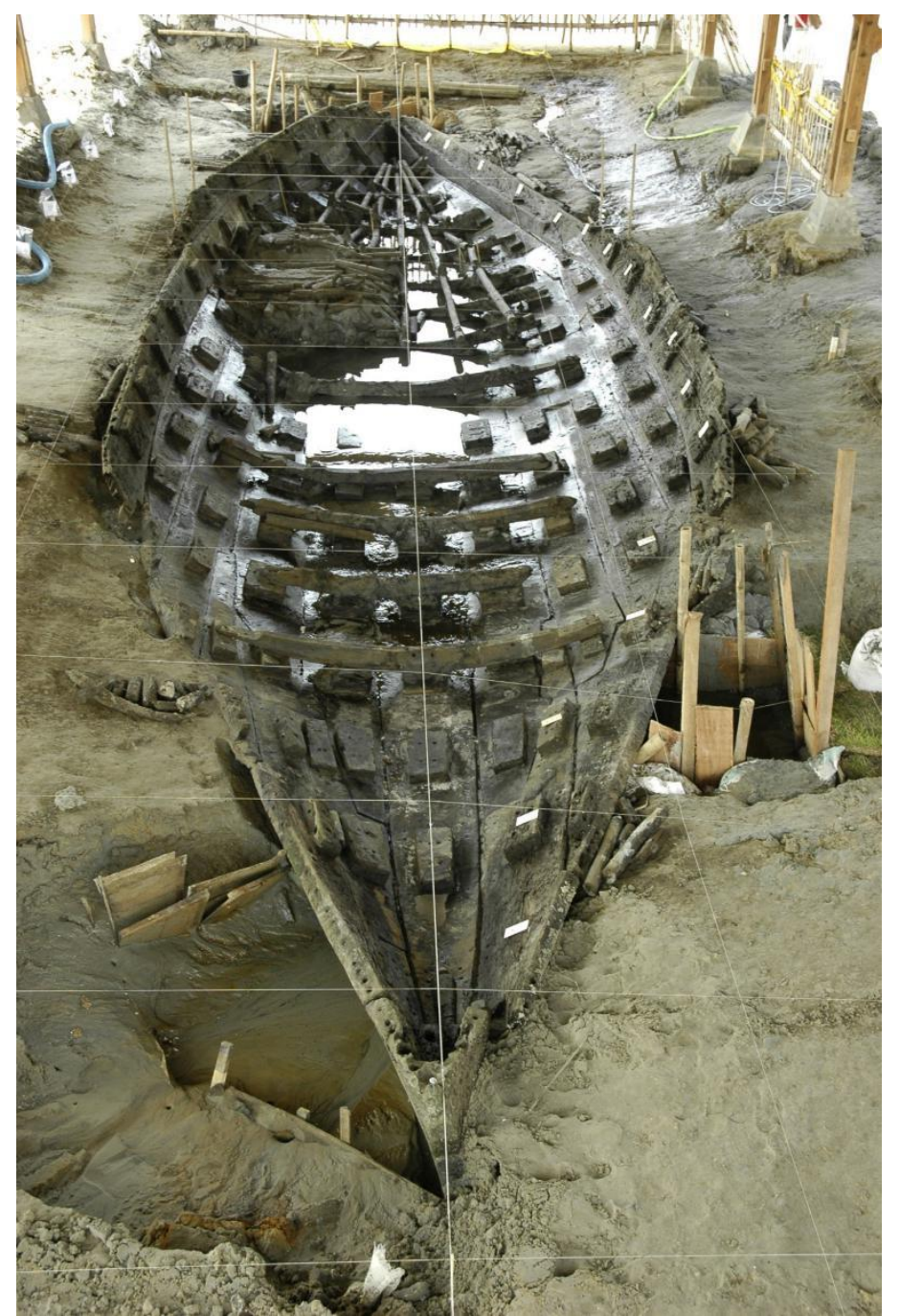

Figure 5. Punjulharjo Boat After the Excavation in 2009, Seen From the Bow (Source: Balar Prov. DIY)

In 2011, Direktorat Peninggalan Cagar Budaya dan Permuseuman (Dit. PCBM) decided to become involved in the conservation and management of the site. They asked Balai Konservasi Borobudur - an institution specialising in heritage conservation - to prepare a conservation plan for the boat (Dit. PBA, 2011). The conservation process started in 2013 and finished by the end of 2017. During these years, the boat timbers were not accessible because they were submerged in polyethylene glycol (PEG) so Dit. PCBM put up information panels about the boat for visitors. These boards provided descriptions of the findings and the conservation process, as well as the results from the latest research on the boat.

On November 2017, the shelter was demolished, and Dit. PCBM started to build a new one. The new shelter finished two months later, resulting in a semiopen building that housed the boat. The boat was reassembled and placed approximately at its original finding location, although with a different elevation since it was raised above the floor surface for display (Figure 6). Although the new arrangement of the site was more suitable as an exhibition, it seemed that the 
shelter was not suitable to maintain the condition of the timbers and could cause damage in the long run. The shelter was a semi-open construction which exposes the boat to the rather harsh weather of the coastal area.

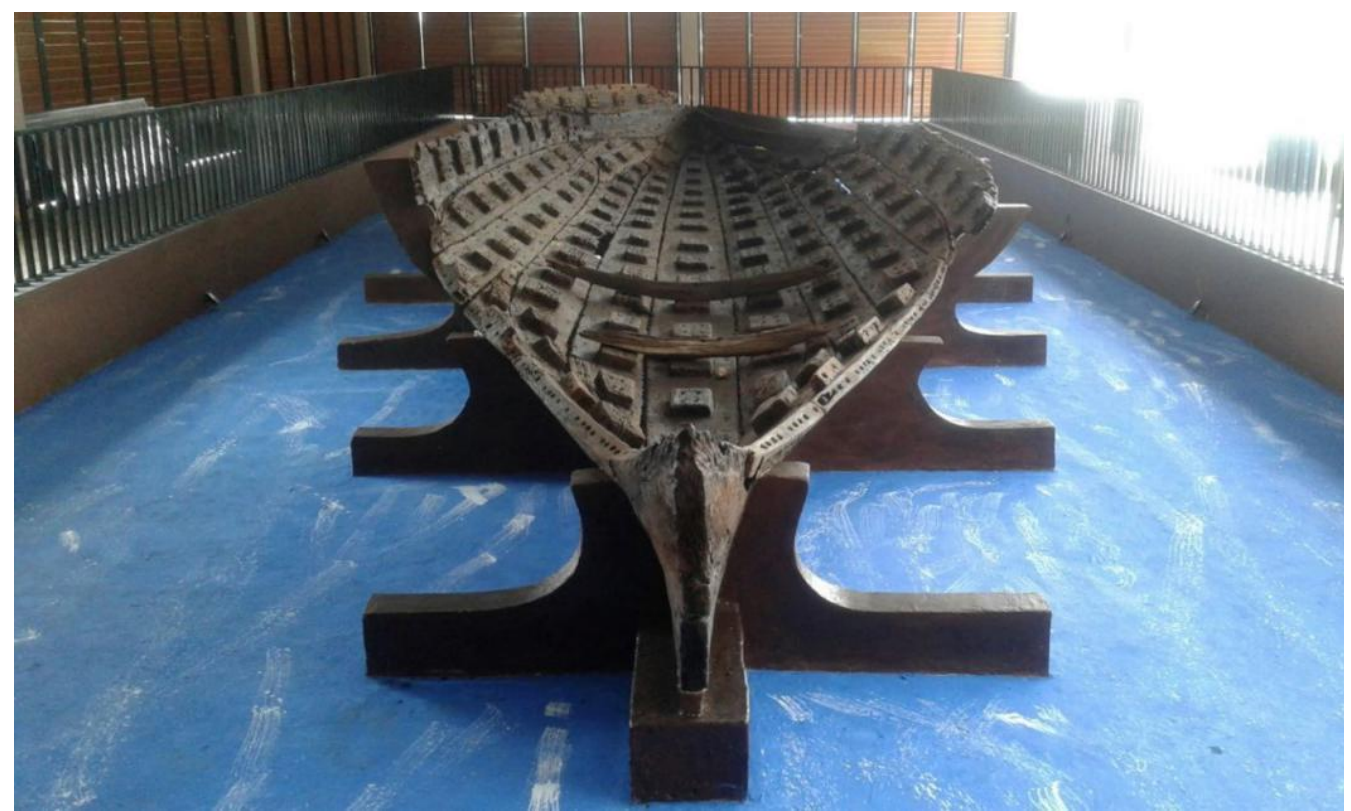

Figure 6. The Condition of Punjulharjo Boat After Conservation (Source: Dit. PCBM, January 2018)

\section{Archaeological Assessment}

\section{General condition}

The boat is originally found in sandy soil of a salt-evaporation pond. After four years of conservation treatment, the boat is currently being displayed in a semi-open structure, built on top of the finding location (Figure 7). During the survey to the site between November 2017 and January 2018, the author observed the last phase of conservation work; the reconstruction process of the boat remains, as well as the construction work of the exhibition building. From the observation, it is clear that there are several differences between the re-assembled boat and its original condition. Thus, the archaeological assessment of the boat consists of result from previous research and its state during the survey.

\section{Previous archaeological research}

In 2009, the boat had a nearly complete hull, with the bow and stern were still intact. Missing several upper strakes, the boat was 15.6-m long, 4.6-m wide, and 1.2-m deep. Series of lugs were carved out of each strake on the inside of the hull. Each strake consisted of two to four planks to shape the curvature of the boat. A single wood keel plank served as the backbone of this vessel (Sulistyarto, 2013, p. 56).

Inside the hull, especially toward the aft, various forms of fitting such as frames, stringers, and beams were still intact (Figure 8). These fittings provided 
strength to the hull structure. The frames were lashed with ropes, made from palm sugar fiber, onto the lugs to provide transversal strengthening. On top of the frames, the boat master placed stringers longitudinally from the bow to stern. The stringers were lashed onto the frames, also using ropes. Stanchions then were attached to the stringer to support the beams, which not only added strength to the hull, but also served as the floor or seating area (Abbas, 2013, pp. 42-43).

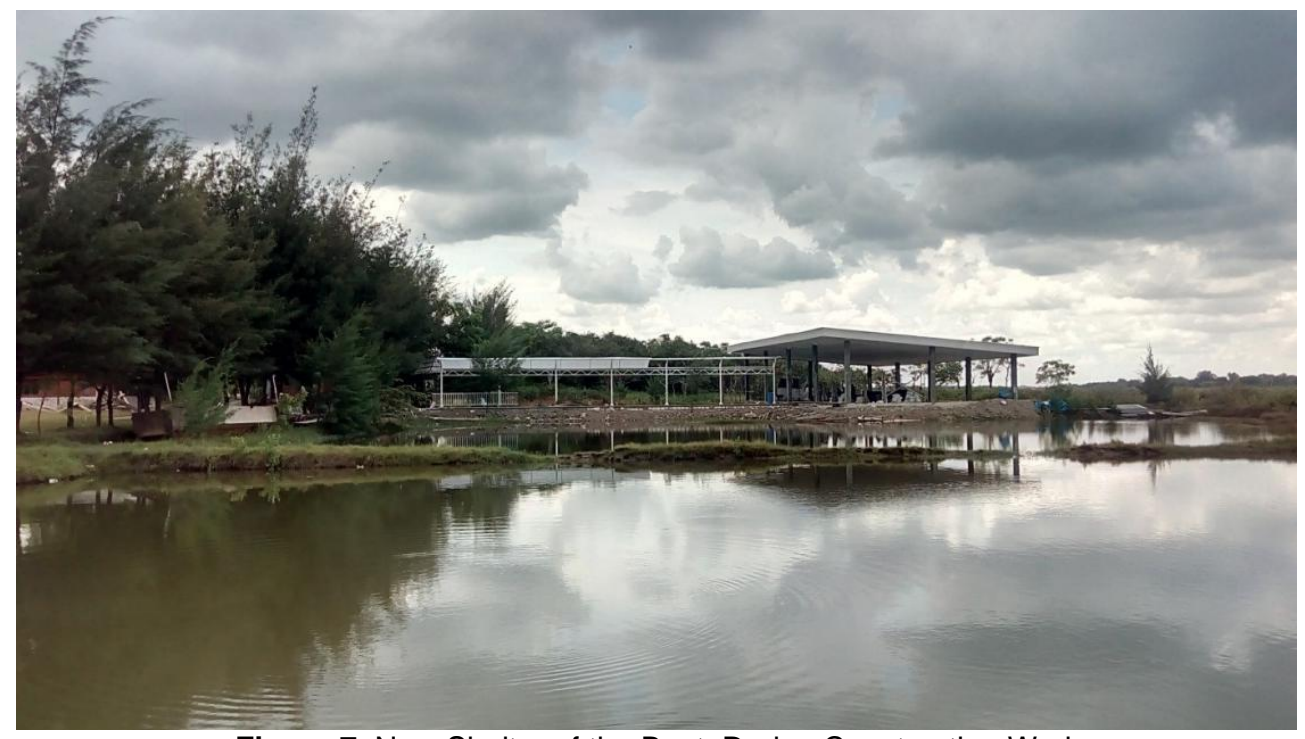

Figure 7. New Shelter of the Boat, During Construction Work (Source: A. Mochtar, 2 January 2018)

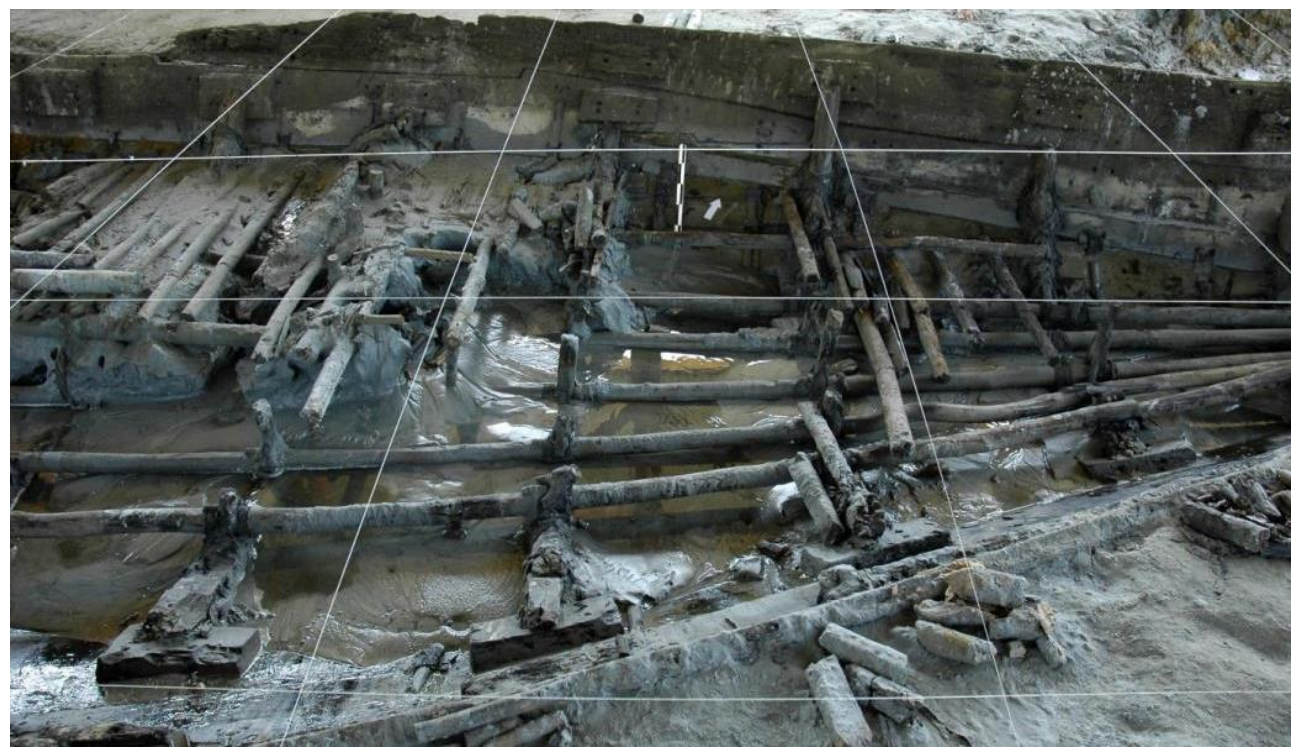

Figure 8. Fittings of Punjulharjo Boat During Excavation in 2009 (Source: Balar Prov. DIY) 


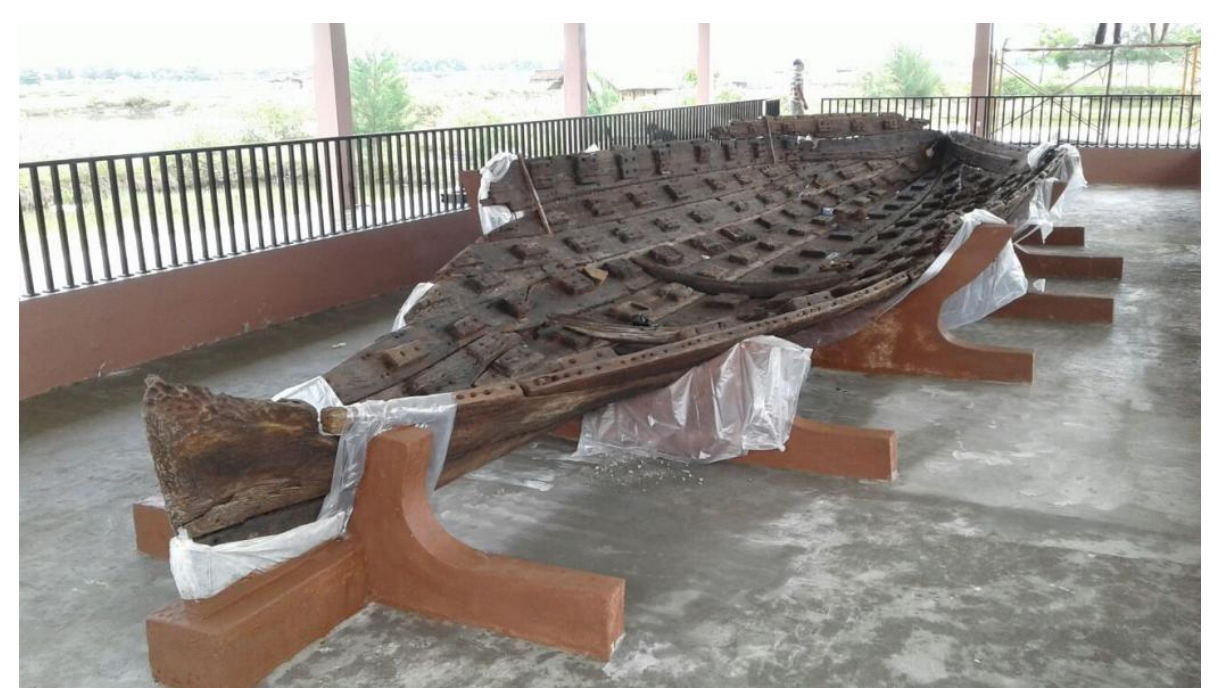

Figure 9. Re-assembled Boat With Concrete Supports

(Source: Idhom, January 2018)

\section{Survey results}

The re-assembled boat displays a remarkable result of lengthy conservation work. The dimension of the boat slightly alters from the initial condition, possibly because the new concrete supports have a different curvature with the original sandy soil context (Figure 9). The reassembled boat has now a total length of $15.6 \mathrm{~m}, 3.6 \mathrm{~m}$ on its widest beam, and $1.1 \mathrm{~m}$ on the depth. The same amount of strake is evident, six strakes on the starboard side and five stakes on the port side. Only a small number of degraded timbers are seen on the hull, compared to its finding condition (Figure 10). All strakes are attached to a piece of wing end, both on the bow and stern.

The lugs (or tambuku in Malay) on each strake of the hull, are the particular feature of this boat. They confirm that the boat belongs to the lashed-lugs tradition, one of the traditional boat building in Southeast Asia. In this type of watercraft, the frames are fastened to the hull by lashing them with vegetable-fiber rope to the lugs (Manguin, 2009, p. 4). Lashings in Punjulharho boat, however, are not limited to tie the frames, but also to join a plank to other planks. A pair of holes is drilled on each corner of a lug (Figure 11), forming an L-shape, so the other ends are on the seam of the planks (Figure 12). Each pair adjoins with another pair on the other plank. A rope runs through this set of four holes forming a lashing to attach two planks (Mochtar, 2018). Although slightly discreet, a small section of rope is still attached to a few ligature holes.

The lashing and treenails are the primary fastenings used in the Punjulharjo boat. Mortises and tenons appear as additional fastening on the planks near the boat extremities (Mochtar, 2018). All three fastening work to attach the hull planks on each other's edge, known as carvel or edge-joined planking. This planking is one of the two planking system used in wooden shipbuilding, besides clinker planking where one edge of a plank is placed on top of another plank's edge. Where watercraft uses ligature as fastening, sometimes the hull is not smooth, despite the carvel planking, because the ropes can be seen from the outside. This 
is, however, not the case for Punjulharjo boat where all the lashings stay inside the hull.

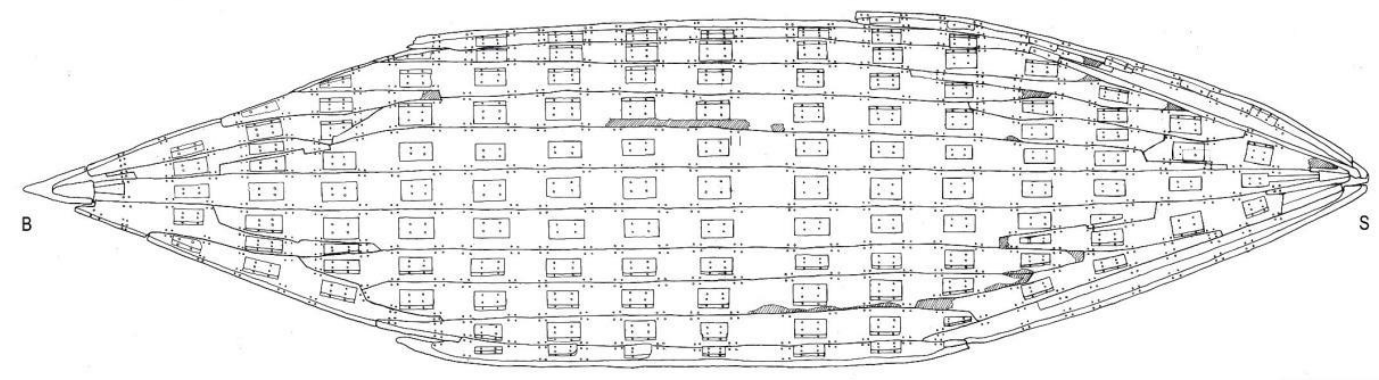

Figure 10. Plan of Punjulharjo Boat, Bow on the Right and Stern on the Left (Source: A. Mochtar, 2018, p.29)

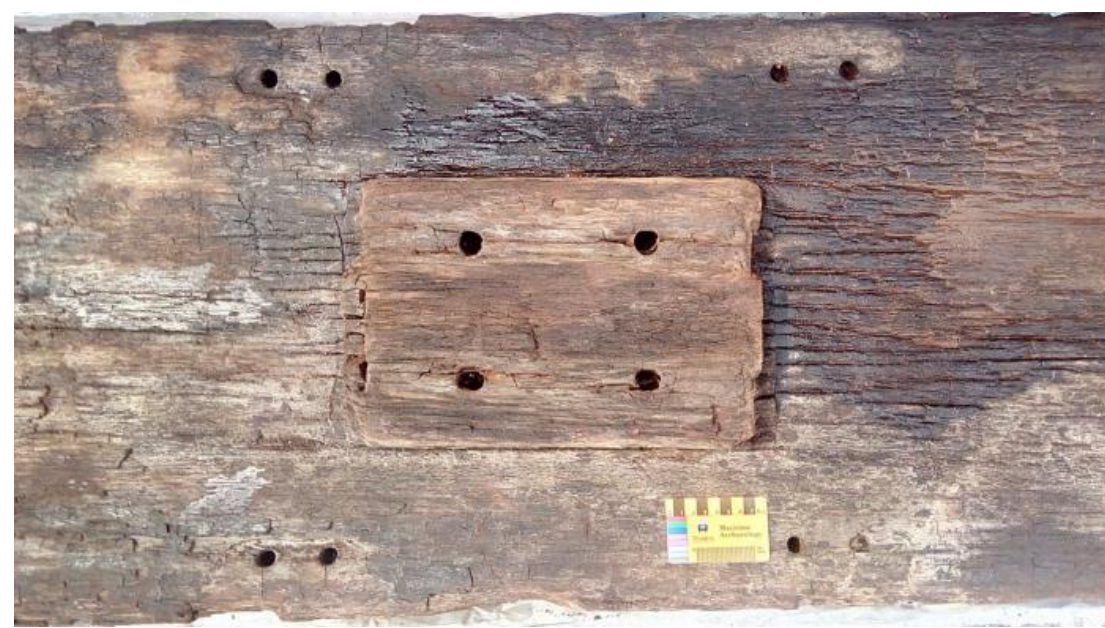

Figure 11. A Lug With Ligature Holes on Each Corner (Source: A. Mochtar, 18 November 2017)

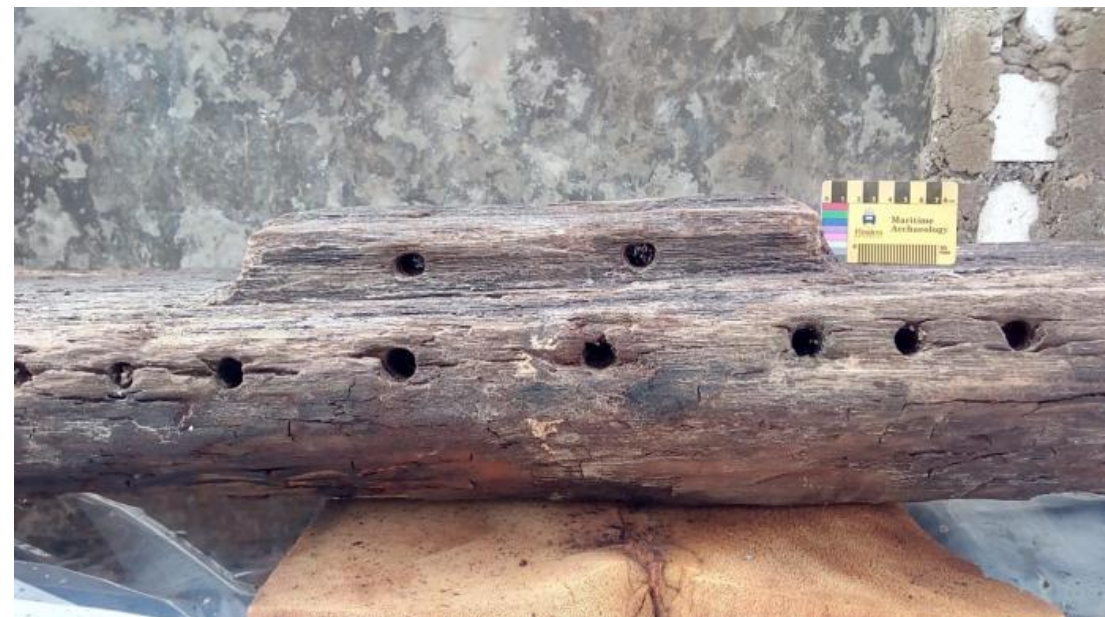

Figure 12. The Seam of the Keel Plank, Showing Holes for Ropes and Treenails (Source: A. Mochtar, 18 November 2017) 
The major difference seen on the re-assembled boat is the absence of the fittings components from the inside of the hull, aside from two fragments of frame are placed near the bow (Figure 13). These two pieces of frame fragment are $1 \mathrm{~m}$ and $1.5 \mathrm{~m}$ each in length. They are both trapezoidal in cross-section. The rest of the remaining frame is still treated with PEG 4000 during the survey. Most of them are already broken into smaller pieces and might need extra effort to re-assemble them (Figure16). The similar condition happens to the stringers and stanchions. The real misfortune of all is none of the rope survives, other than tiny bits of them, measures no longer than $5 \mathrm{~cm}$.

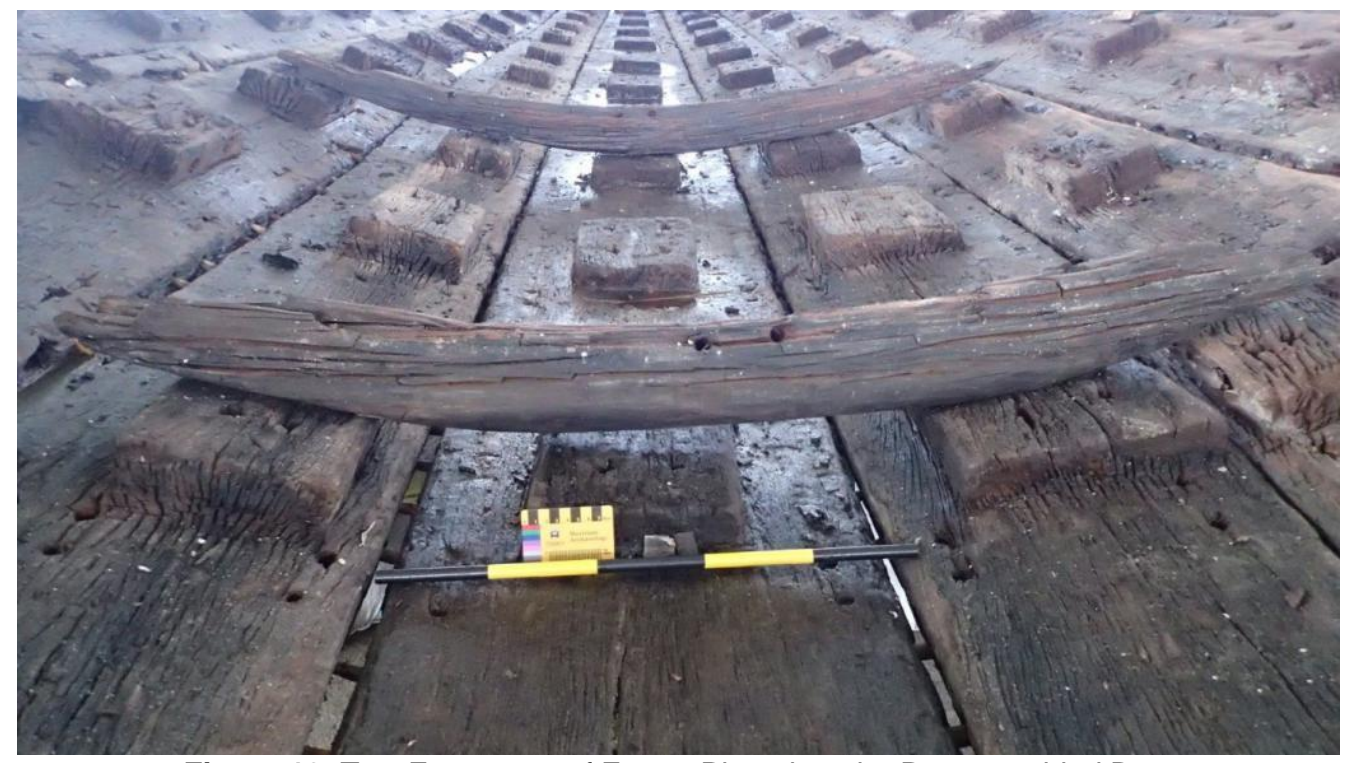

Figure 13. Two Fragments of Frame Placed on the Re-assembled Boat

(Source: A. Mochtar, 30 December 2017)

The main issue for the Punjulharjo site is how the coastal tropical weather affects the perishable materials of the boat. The degradation process of the timbers, bamboo, and palm-sugar fibers rapidly accelerates after the excavation finished in 2009 and before the conservation started in 2013, when the boat remains were exposed to the weather without proper protection. The process resulted in varying degrees of damage to the boat's components.

\section{a. Deterioration of the major components}

The major components of the Punjulharjo boat comprise of the keel plank, hull planks, and wing-ends. These timbers show the different stages of deterioration, but the result of a flaking process can be seen in almost all of them. Several planks have severe flaking, where some parts have fallen off the plank (Figure 14). Some lugs have also deteriorated and lost their original form (Figure 15).

The conservation of the timbers that have been done should increase their durability and significantly decrease this flaking process. However, this might not be enough, as the boat is currently being put back on display in a semi-open shelter, still exposed to the harsh weather. Without a continuous conservation 
plan, it is likely that the deterioration of the boat remains will worsen rapidly and the site will lose elements of its significance.

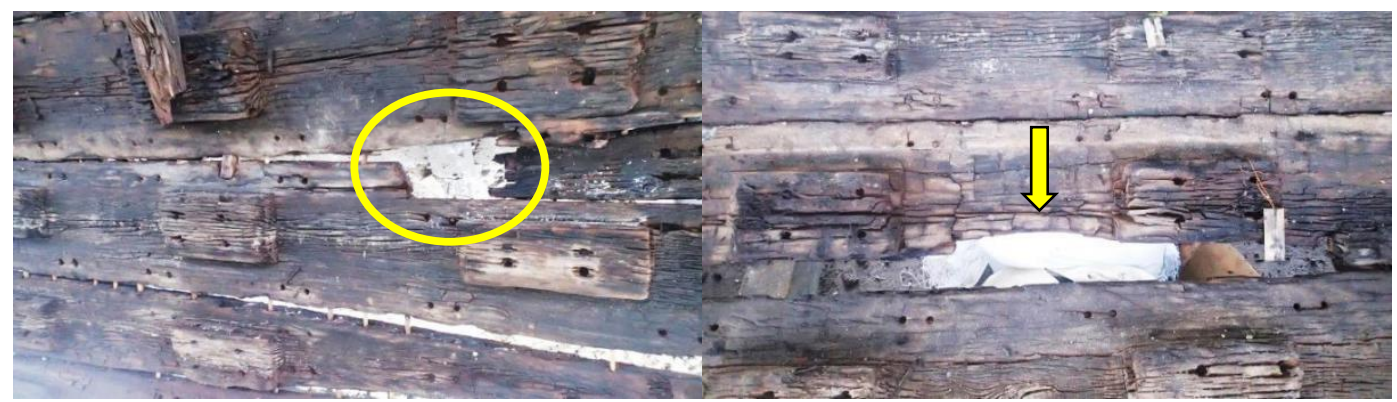

Figure 14. Damaged Planks Caused by a Flaking Process (Source: A. Mochtar, 2January 2018)

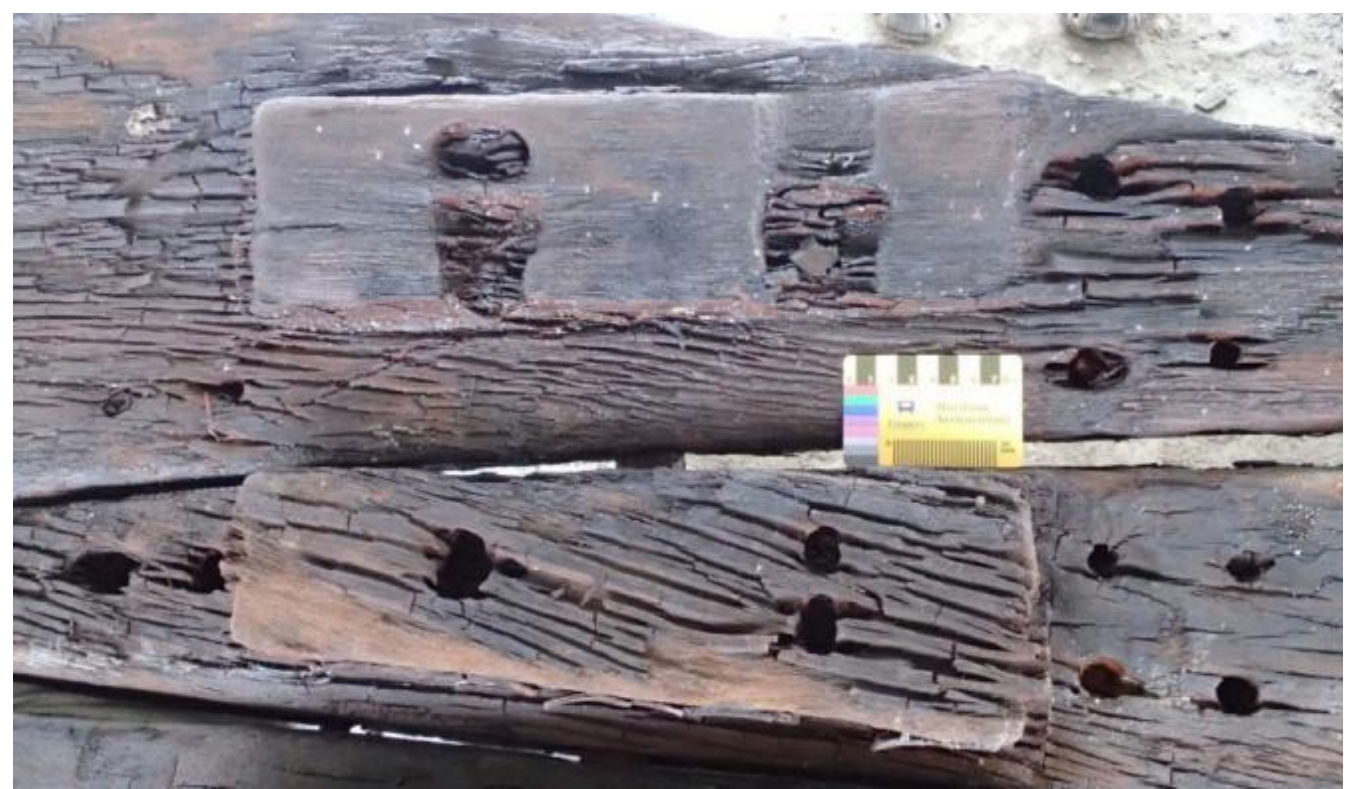

Figure 15. Deformation of a Lug (upper), After Long Exposure to Coastal Weather (Source: A. Mochtar, 29 December 2017)

b. Damage of the minor components

The currently displayed boat is missing its minor components, such as the frames, stringers, and the ropes that tied them to the hull. Most of the frames and stringers, as well as beams, have fractured into small pieces (Figure 16) and only a few sections of ropes survive because they are protected inside the ligature holes. These components are of high archaeological and historical significance because there are less than a handful of vessels from the lashed-lug tradition in Southeast Asia found with them still intact. Every piece has been treated with Polyethylene glycol during the conservation process, but the damage is irreversible. Without any attempts to reconstruct them, the information of the fastenings and strengthening system of the boat will be absent, and the site will lose one of the main elements of significance. 


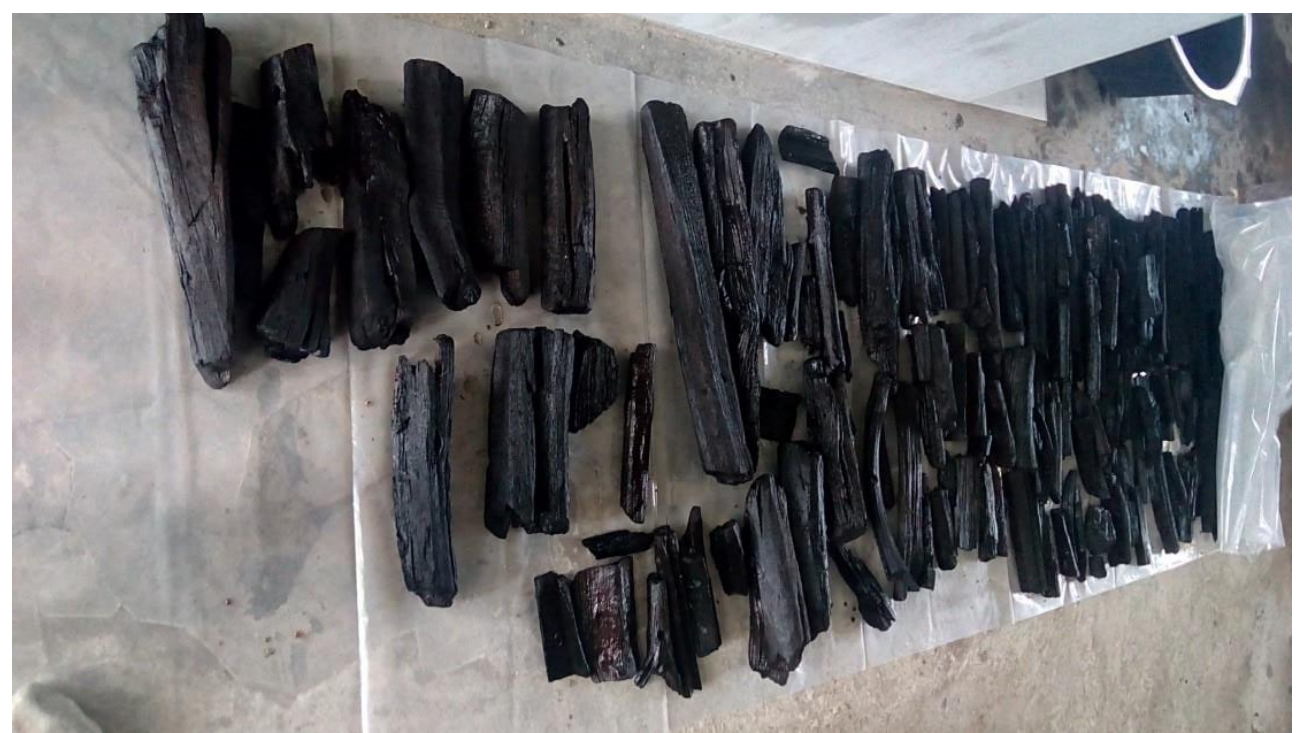

Figure 16. Fragments of Frames, Stringers, and Beams (Source: A. Mochtar, 20 November 2017)

\section{Administrative Context}

\section{Stakeholders}

The boat was found by the local people, and for a few years, they involved in taking care of the site by collaborating with heritage agencies. They assisted Balar Prov. DIY during the excavation and helped build the first shelter for the boat. However, only a small number of people joined this group, while the majority of the villagers seemed to have less interest in engaging with the heritage site in their neighborhood. Balar Prov. DIY handed over the authority of the site to BPCB Jawa Tengah after they finished excavating the boat in 2009, but data from the research, such as reports, drawings, and photographs, as well as the majority of artefacts from the site are kept in their office.

Later, Dit. PCBM took over the management of the site by authorising and funding the conservation of the boat remains and the construction of the in situ exhibition shelter. However, BPCB Jawa Tengah is still responsible for the maintenance of the site. This includes appointing a local as the site caretaker. Balai Konservasi Borobudur conducted the conservation work, on behalf of Dit. PCBM. In the late 2018, Dit. PCBM gave the authorization to manage the site to the Government of the District of Rembang, particularly under Dinas Kebudayaan dan Pariwisata. Aside from the responsibility of the conservation work that is hold by BPCB Jawa Tengah, the Government of the District of Rembang currently leads the management of the Punjulharjo Site.

\section{Legislative context}

The primary legislation to protect Punjulharjo site, as well as all heritage places in Indonesia, is the Law of the Republic of Indonesia Number 11 of 2010 Concerning Cultural Conservation. Even though this site is a shipwreck site, the Regulation of the Minister of Culture and Tourism No. 48 of 2009 on Guidelines 
for Management of Underwater Heritage Culture and Tourism would not be applicable since it does not cover a wide range of maritime cultural heritage, but mainly concerns only with the ones found underwater.

According to the Law of the Republic of Indonesia Number 11 of 2010 Concerning Cultural Conservation (Article 1), cultural heritage is any material cultural inheritance, including an object, building, structure, site, and geographical space unit, located on land and/or in water, which is needed to be preserved due to its significance for history, science, education, religion, and/or culture, through the stipulation process. Article 9 of the act specifies that Cultural Conservation Site is a location that:

- Contains heritage object, building, and/or structure; and

- Stores information of humans' activities in the past.

It is, therefore, required to address Article 5 as it specifies the criteria of heritage object, building, and/or structure, as follows:

- It is fifty years old or more;

- It represents a style that is a minimum of fifty years old;

- It holds a specific meaning for history, knowledge, education, religion, and/or culture; and

- It holds cultural value for the national character building.

The Law of the Republic of Indonesia Number 11 of 2010 Concerning Cultural Conservation acknowledges archaeological artefact as one of the types of heritage, or heritage objects. It also makes provisions about artefact that are still buried under land surface or underwater in Article 26, which says that they are protected as alleged heritage objects. Thus, they can only be found through research, and any accidental finding must be reported directly to the heritage agency.

\section{DISCUSSIONS}

\section{Assessment of Significance}

This assessment of significance of the Punjulharjo Site is amassed from various sources, including previous research reports, scholarly publications, data from fieldwork, Register of National Cultural Conservation, as well as on-site observation. These sources provide information about the values of the site that meet the criteria of heritage stated in the Law of the Republic of Indonesia Number 11 of 2010 Concerning Cultural Conservation, as the primary legislation for the protection of cultural heritage in Indonesia. Referring back to the law, certain location can be stipulated as Cultural Conservation Site if it contains Cultural Conservation Object, Building, and/or Structure. Therefore, to assess the significance of the site needs to be initiated by, if not fully-based on, assessing the said object/building/structure. For the Punjulharjo Site, the significance of the site equals the significance of the boat, because the boat is the sole object on the site. While adequate information of the object is obtained, the community perspective towards the site is not, due to the absence of structured interview to local people during the fieldwork. Thus, the value of the site from the perspective of the community, although mentioned, is rather incomprehensible. 


\section{Overall significance}

The Punjulharjo boat is, by far, the most complete wooden shipwreck found in Indonesia. A well-preserved wooden object, let alone almost the whole hull of a vessel, is a rarity in the tropical waters and coastal area. The boat is neither the only nor the oldest ancient watercraft remains, however, it is the only lashedlug vessel found with the intact hull, together with the fastenings and fittings inside it. The Punjulharjo boat is the first and, so far, the only nautical archaeology finding in Indonesia that has been undergone a thorough conservation treatment and thus currently accessible to the public.

The Punjulharjo boat is also significant in the Southeast Asian maritime archaeology context, since the lashed-lug tradition is not particular to Indonesia, but rather also common in the region. The tradition is the descendant of Austronesian culture, which is also introduced as far as to Madagascar on the west and the Pacific on the east (Horridge, 1995; Manguin, 2016). Similar vessels from the neighboring countries also suffer the non-existence of many components, other than the hull planks. The Punjulharjo boat holds key answers to further the knowledge of the widely dispersed traditional boat building.

\section{National level of significance}

The Law of the Republic of Indonesia Number 11 of 2010 Concerning Cultural Conservation mentions in Article 5 the criteria of Cultural Conservation Object as follows:

a. It is fifty years old or more

The age of the Punjulharjo boat is revealed from a radiocarbon dating of the rope samples. The result shows the years of 660-780 CE(Abbas, 2013, p. 42), which does not only meet the age criteria of a Cultural Conservation Object but also comes as the second oldest dating of boat remains found in Indonesia. Kolam Pinisi boat in Palembang has the oldest dating of 434-631 CE (Lacsina, 2016, p. 125).

b. It represents a style that is a minimum of fifty years old

The Punjulharjo boat represents the lashed-lugs watercraft. This type of boat/ship is no longer exist in Indonesia, aside from in one small island in eastern Indonesia (Barnes, 1985). The oldest boat remains from the lashed-lugs tradition dated from the fifth century (Lacsina, 2016, p. 125). The tradition itself has had technical changes throughout over a millennium. The older vessels, dated before the tenth century, are fastened with treenails and ligatures. Meanwhile, since the tenth century, the ligatures are only used to lash the frame to the hull, but not to tie one plank to another (Manguin, 2016, pp. 62-63). Thus, the Punjulharjo boat represents a certain style of boat building technique that is not only over fifty years old, but also already extinct.

c. It holds a specific meaning for history, science, education, religion, and/or culture 


\section{History}

The Punjulharjo boat can contribute to two aspects of Indonesian history; the maritime history and the history of Austronesian dispersal. The maritime history of Indonesia is still poorly written, due to an inadequate amount of research in the field. Detailed studies of the Punjulharjo boat will add a sizable portion to the narrative of the maritime history, especially of those from the first millennium. As for the history of Austronesian culture, Punjulharjo becomes one of the sites of the late period of Austronesian dispersal in Indonesia before they began to colonise Madagascar in, presumably, the eighth century (Cox et al., 2012).

\section{Science}

Studies of the remaining components of the Punjulharjo boat will lead to a further understanding of the boat building technique that has been practised in Indonesia since over a thousand years ago. This understanding provides new knowledge of how the ancestor mastered the skills to adapt to the archipelagic environment. The skills include the exploration of natural resources for raw materials, the building technique of the vessel, and the method of navigating their way in between the islands.

\section{Education}

During the fieldwork in 2018, many visitors came to the site with high curiosity about the boat. Almost all of them asked for information about the boat either from the caretaker of the site or from the fieldwork team (Figure 17). Some of them were students who were willing to spend more than half an hour to listen and discuss the boat with the team. This situation captured the potential of Punjulharjo site to become a resource of education about history and archaeology to the public, especially about the maritime archaeology.

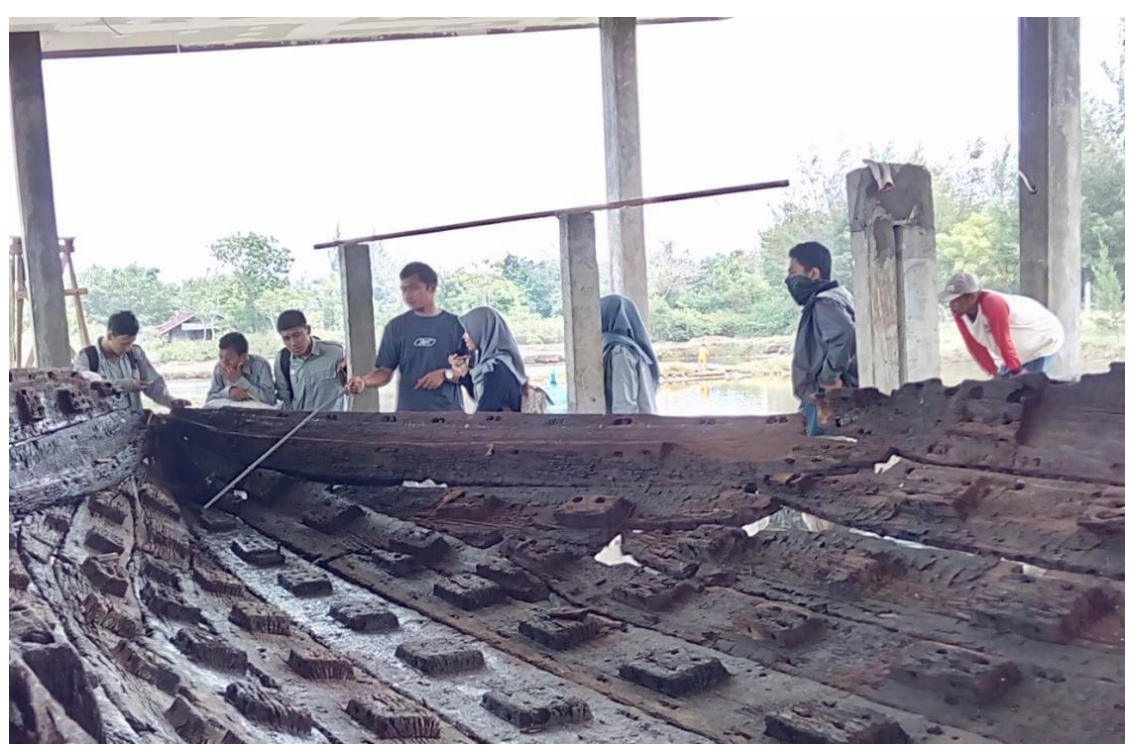

Figure 17. One of the Fieldwork Team Members Discusses the Boat With Local Students (Source: A. Mochtar, 30 December 2017) 
d. It holds cultural value for the national character building.

The current president of Indonesia has announced that maritime culture as one of the fundamental Indonesian national characters. This statement is later embodied in various government maritime-based programs, one of them is the encouragement of maritime history as the foundation of national character (Rencana Strategis Sekretaris Kabinet 2015-2019, 2016). The Punjulharjo boat provides a rich cultural value as one of the rare physical evidence of maritime activity in ancient times, as it shows how the ancestor saw the ocean as the connector, instead of the divider, of islands in Indonesia.

\section{Regency level of significance}

The Decision of Regent of Rembang No. 05 of 2014 on the Management of Cultural Heritage adopts the criteria of Cultural Conservation from the Law of the Republic of Indonesia Number 11 of 2010 Concerning Cultural Conservation. Whereas other points are similar to the national level of significance, point (c) has additional local value.

c. It holds a specific meaning for history, science, education, religion, and/or culture

\section{History/Education}

Local people are familiar with the folklore of Dampo Awang, the boat master that brought Islam to Rembang in around the thirteenth century (Septyana, 2012, pp. 102-106). It is not uncommon to hear the visitors who come to Punjulharjo site mentioning that the boat is Dampo Awang's vessel. This misconception is due to, probably, the lack of knowledge about the history of their hometown beyond the arrival of Islam. Punjulharjo boat, thus, can serve as a source of information to aid in the writing of the local history, as well as to educate the locals about their history.

\section{Management Objectives and Implementation Strategy}

This Cultural Heritage Site Management Plan is outlined into several objectives and implementation strategy. The objectives are designed to meet the preservation policy stated in the Law of the Republic of Indonesia Number 11 of 2010 Concerning Cultural Conservation under Section VII. The preservation consists of three groups; protection, development, and utilization. Protection of Cultural Conservation in Indonesia includes salvation, safeguarding, zoning, maintenance, and restoration. Meanwhile, development covers research, revitalization, and adaptation.

This plan is to be implemented by the Government of the District of Rembang, especially Dinas Kebudayaan dan Pariwisata, who holds the main responsibility of managing the site, in collaboration with BPCB Jawa Tengah. The responsibility set out in this plan is to be divided between the two institutions to make sure that the implementation strategy will be executed adequately to achieve the outlined objectives. Dinas Kebudayaan dan Pariwisata should authorize the actions within the regency context, such as building up networks with local schools 
and university, as well as the daily maintenance of the site. Meanwhile, BPCB Jawa Tengah should authorize the actions that are related to archaeological aspects, especially the conservation of the site, due to the lack of expertise in this field in the local institution.

\section{Management Objectives}

Management Objective 1: Implement a long-term protection plan for the site

The Punjulharjo Site is listed in the Register of National Cultural Conservation as a Cultural Conservation Site, according to the Regulation of the Minister of Culture and Tourism No. 57 of 2010. However, the then Minister passed this regulation prior to the enacting of the Law of the Republic of Indonesia Number 11 of 2010 Concerning Cultural Conservation. Some details about the heritage status of the boat, thus, are missing. The details consist of the classification of the site; whether it is of national, provincial, or regency/municipal level, as well as the zoning of the site.

Therefore, it is essential to make sure that the missing requirements are met in accordance to the current law for a full protection of the site. The updating of the information about the site in the Register of National Cultural Conservation and establishing the zoning of the site to administer types of activity that are allowed to be conducted on the site are essential to be done.

This objective refers to Section VI (Register) and Section VII.2.3 (Article 7274 Zoning) of the Law of the Republic of Indonesia Number 11 of 2010 Concerning Cultural Conservation.

Management Objective 2: Maintain the condition of each element of the boat remains

The conservation of the boat remains undertaken from 2013 to 2017 has reached a quite satisfying result in terms of stabilizing the timbers for an exhibition. This is, however, only the first phase of a continuous conservation plan that needs to be implemented to the site. This plan should also consider the environmental factor that will highly impact the timbers to make sure that further deterioration of the timber is mitigated.

This objective refers to Section VII.2.4 (Article 75-76 Conservation) of the Law of the Republic of Indonesia Number 11 of 2010 Concerning Cultural Conservation.

Management Objective 3: Reconstruct the original internal strengthening system of the boat

The current state of the boat remains is still missing the internal strengthening system intact to the hull when the boat was found. Considering the significance of these elements, it is critical to conduct archaeological research and might not omit the aid of ethnography and experimental study. The result of the research should be followed by a reconstruction of the remaining strengthening elements by the archaeologists.

This objective refers to Section VII.2.5 (Article 77 Restoration) and Section VII.3.2 (Article 79 Research) of the Law of the Republic of Indonesia Number 11 of 2010 Concerning Cultural Conservation. 
Management Objective 4: Increase public engagement

The site is the only shipwreck site that is accessible by the public. It is, therefore, necessary to apply a revitalization plan to the site to enhance the chance of public engagement with the site. The plan comprises of programs and activities that will make the site more attractive and accommodating the visitors. Included also in the plan is a set of guidelines to utilize the site. The guidelines provide information on how the public can engage in a variety of activities and regulate how such activities will be undertaken.

This objective refers to Section VII.3.3 (Article 80-82 Revitalization) and Section VII.4 (Article 85-94 Utilization) of the Law of the Republic of Indonesia Number 11 of 2010 Concerning Cultural Conservation.

\section{Implementation strategy}

Implementation strategy is outlined in a series of actions for each management objective, to achieve the intended outcome. This following plan outlines the actions that need to be undertaken by the managing institution(s) to guarantee that the aim of the management plan is met. Included in the plan is organisation/institution that might assist to perform an adequate action, and type of resources that need to be prepared beforehand, and monitoring system for each action.

Table 1.The Action Plan for Management Objectives

\begin{tabular}{|c|c|c|c|c|c|}
\hline $\begin{array}{c}\text { Management } \\
\text { objective }\end{array}$ & Action & Outcome & Consultation & Resource & $\begin{array}{l}\text { Monitor and } \\
\text { review }\end{array}$ \\
\hline $\begin{array}{l}\text { Implement a } \\
\text { long-term } \\
\text { protection } \\
\text { plan for the } \\
\text { site }\end{array}$ & $\begin{array}{l}\text { Execute the } \\
\text { stipulation } \\
\text { process of } \\
\text { classifying the } \\
\text { site } \\
\text { (Dinas / Dit. PK) }\end{array}$ & $\begin{array}{l}\text { Decree/ } \\
\text { decision of the } \\
\text { stipulation of } \\
\text { the } \\
\text { classification of } \\
\text { the site } \\
\text { (National/ } \\
\text { regency) }\end{array}$ & $\begin{array}{l}\text { Consult the } \\
\text { Cultural } \\
\text { Conservation } \\
\text { Expert Team for } \\
\text { recommendation } \\
\text { of site } \\
\text { classification }\end{array}$ & $\begin{array}{l}\text { Funding for } \\
\text { consultants } \\
\text { Recommen- } \\
\text { dation on } \\
\text { stipulation }\end{array}$ & $\begin{array}{l}\text { Semester } \\
\text { progress report by } \\
\text { the stipulation } \\
\text { team }\end{array}$ \\
\hline & $\begin{array}{l}\text { Execute the } \\
\text { stipulation } \\
\text { process of the } \\
\text { zoning system of } \\
\text { the site } \\
\text { (Dinas / Dit. PK) }\end{array}$ & $\begin{array}{l}\text { Decree/ } \\
\text { decision of the } \\
\text { stipulation of } \\
\text { the zoning } \\
\text { system }\end{array}$ & $\begin{array}{l}\text { Consult } B P C B \\
\text { Jawa Tengah }\end{array}$ & $\begin{array}{l}\text { Funding for } \\
\text { fieldworks } \\
\text { Tools: maps, } \\
\text { drone, GPS } \\
\text { Stipulation } \\
\text { draft }\end{array}$ & $\begin{array}{l}\text { Semester } \\
\text { progress report by } \\
\text { the stipulation } \\
\text { team }\end{array}$ \\
\hline $\begin{array}{l}\text { Maintain the } \\
\text { condition of } \\
\text { each element } \\
\text { of the boat } \\
\text { remains }\end{array}$ & $\begin{array}{l}\text { Maintenance of } \\
\text { the timbers by } \\
\text { applying } \\
\text { preservative } \\
\text { (BPCB Jawa } \\
\text { Tengah) }\end{array}$ & $\begin{array}{l}\text { A controlled } \\
\text { condition of the } \\
\text { timbers }\end{array}$ & $\begin{array}{l}\text { Consult the } \\
\text { heritage } \\
\text { conservation } \\
\text { agency (Balai } \\
\text { Konservasi } \\
\text { Borobudur) }\end{array}$ & $\begin{array}{l}\text { Funding for } \\
\text { consultants } \\
\text { Funding for } \\
\text { fieldworks }\end{array}$ & $\begin{array}{l}\text { On-going monitor } \\
\text { of deterioration } \\
\text { level. } \\
\text { Report every } 3 \\
\text { months. }\end{array}$ \\
\hline
\end{tabular}




\begin{tabular}{|c|c|c|c|c|c|}
\hline $\begin{array}{c}\text { Management } \\
\text { objective }\end{array}$ & Action & Outcome & Consultation & Resource & $\begin{array}{c}\text { Monitor and } \\
\text { review }\end{array}$ \\
\hline $\begin{array}{l}\text { Reconstruct } \\
\text { the original } \\
\text { internal } \\
\text { strengthening } \\
\text { system of } \\
\text { boat }\end{array}$ & $\begin{array}{l}\text { Conduct research } \\
\text { to understand the } \\
\text { original system } \\
\text { (Dinas) } \\
\text { Reconstruct the } \\
\text { strengthening } \\
\text { system using the } \\
\text { original timbers } \\
\text { with the addition } \\
\text { of new timbers } \\
\text { and fibre ropes } \\
\text { (Dinas) }\end{array}$ & $\begin{array}{l}\text { A reconstructed } \\
\text { fitting to be } \\
\text { placed inside } \\
\text { the hull }\end{array}$ & $\begin{array}{l}\text { Consult the } \\
\text { archaeological } \\
\text { research } \\
\text { institution (Balar } \\
\text { Prov. DIY) }\end{array}$ & $\begin{array}{l}\text { Funding for } \\
\text { consultants } \\
\text { Funding for } \\
\text { fieldworks } \\
\text { Materials for } \\
\text { recon- } \\
\text { struction }\end{array}$ & $\begin{array}{l}\text { Progress report by } \\
\text { the research team } \\
\text { On-going } \\
\text { monitoring and } \\
\text { conservation of the } \\
\text { reconstructed } \\
\text { elements }\end{array}$ \\
\hline $\begin{array}{l}\text { Increase } \\
\text { public } \\
\text { engagement }\end{array}$ & $\begin{array}{l}\text { Establish } \\
\text { interpretation and } \\
\text { install information } \\
\text { board } \\
\text { (Dinas) } \\
\text { Create guided } \\
\text { tour (Dinas) } \\
\text { Collaborate with } \\
\text { local schools and } \\
\text { universities in } \\
\text { developing } \\
\text { educative } \\
\text { program (Dinas) }\end{array}$ & $\begin{array}{l}\text { Share of } \\
\text { knowledge with } \\
\text { visitors } \\
\text { Increased } \\
\text { awareness of } \\
\text { the site from } \\
\text { local people }\end{array}$ & $\begin{array}{l}\text { Consult the } \\
\text { archaeological } \\
\text { research } \\
\text { institution (Balar } \\
\text { Prov. DIY) } \\
\text { Consult the } \\
\text { tourism agency } \\
\text { and school } \\
\text { boards }\end{array}$ & $\begin{array}{l}\text { Funding for } \\
\text { consultants } \\
\text { Tourism } \\
\text { development } \\
\text { plan }\end{array}$ & $\begin{array}{l}\text { On-going } \\
\text { monitoring of the } \\
\text { condition of the } \\
\text { information boards } \\
\text { Annual review of } \\
\text { the program }\end{array}$ \\
\hline
\end{tabular}

\section{CONCLUSION}

The Punjulharjo Site is one of the cultural heritage places in the District of Rembang, Central Java that has been stipulated as Cultural Conservation Site under the Regulation of the Minister of Cultural and Tourism No. 57 of 2010. The site contains a seventh century wooden boat, along with all the associated components, which was found in 2008. The boat was in a remarkable condition, despite the harsh tropical climate on the coastal area. Nearly a decade later, the boat was put on display in situ, after undergone a series of conservation process. The site is unique and likely containing potential information on Indonesian maritime heritage, thus a management plan is required to ensure a long-term protection and preservation of the site.

The result of data analysis for the formulation of the management plan shows that, on the one hand, the Punjulharjo Site holds not only significance in regency level, but in national level. On the other hand, threats are apparent and could impact the boat and the site condition. Therefore, management objectives and the implementation strategy were outlined in accordance to the Law of the Republic of Indonesia Number 11 of 2010 Concerning Cultural Conservation as the principal regulation on cultural property.

While the plan was mostly formulated for the benefit of the Regional Government of the District of Rembang, as the lead institution in the management 
of the Punjulharjo Site, it is clear that BPCB Jawa Tengah and the Directorate of the Cultural Protection (Dit. PK) also hold several key roles in the plan. Moreover, a collaborative works with other heritage agencies such as Regional Agency for Archaeological Research in D.I. Yogyakarta Province and Agency for Borobudur Conservation are important in the implementation of the actions set out to achieve the management objectives.

Every execution of the actions outlined in the plan has to be recorded and must be written in reports. The Regional Government of the District of Rembang should hold a meeting with BPCB Jawa Tengah, at least once a year to review the progress of the implementation of the plan. A joint annual report must, therefore, sent to Dit. PK as the national agency responsible for all Cultural Conservation in Indonesia. This plan should be implemented within five-year time, and a review should be done after that to assess the impact of this plan on protecting and preserving the Punjulharjo Site and to make changes to this plan where necessary.

\section{ACKNOWLEDGEMENTS}

This management plan is designed with the assistance from several institutions and individuals. Permit to access the site was granted by the Directorate of Culture Pledge Conservatio and Museology / Dit. PCBM (now the Directorate of Cultural Protection / Dit. PK) and data from previous research was provided by Regional Agency for Archaeological Research in D.I. Yogyakarta Province. Retna Radityawati, who works for the Regional Government of the District of Rembang, provided information as well as accommodation during the fieldwork. Nahar Cahyandaru, the lead conservator in the Punjulharjo boat conservation project from Agency for Borobudur Conservation who provided information about the conservation process and what could be done in the future of the boat's preservation. The locals (Pak Ikhsan, Mas Idhom, and Pak Nursalim) also provided information about the site. Trisna Mochtar, Ahmad Ramadhan, and Muslim Dimas assisted in the recording of the site. 


\section{BIBLIOGRAPHY}

Abbas, N. (2013). Perahu kuno Punjulharjo: Sebuah hasil penelitian. In I. Andrisijanti (Ed.), Perahu Nusantara (pp. 55-74). Yogyakarta: Kepel Press.

Barnes, R. H. (1985). Whaling vessels of Indonesia. In S. McGrail \& E. Kentley (Eds.), Sewn Plank Boats: Archaeological and Ethnographic paper based on those presented to a conference at Greenwich in November, 1984 (pp. 345-366). B.A.R.

Caixia, L. (2011). The Belitung shipwreck. https://issuu.com/iias/docs/iias_nl58/41

Cox, M. P., Nelson, M. G., Tumonggor, M. K., Ricaut, F.-X., \& Sudoyo, H. (2012). A small cohort of Island Southeast Asian women founded Madagascar. Proceedings Biological Sciences/The Royal Society, 279(1739):2761. https://royalsocietypublishing.org/doi/pdf/10.1098/rspb.2012.0012

Dit. PBA. (2011). Naskah Perencanaan Konservasi Perahu Kuno Punjulharjo.

Hall, K. (2011). A History of Early Southeast Asia: Maritime Trade and Societal Development, 100-1500. Maryland: Rowman \& Littlefield Publishers, Inc.

Horridge, A. G. (1995). Austronesian conquest of the sea - upwind. In P. Bellwood, J. J. Fox, \& D. Tryon (Eds.), The Austronesians: Historical and Comparative Perspectives (pp. 143-160). Canberra: ANU E-Press. https:/ / www.oapen.org/download?type=document\&docid $=458826 \#$ page $=$ 155

ICOMOS. (2017). Salalah Guidelines for the Management of Public Archaeological Sites.

Lacsina, L. (2016). Examining Pre-colonial Southeast Asian Boatbuilding: An Archaeological Study of the Butuan Boats and the Use of Edge-joined Planking in Local and Regional Construction Techniques [Flinders University]. https://www.academia.edu/download/54800536/ThesisLacsina2016.pdf

Liebner, H. (2014). The Siren of Cirebon: A Tenth-Century Trading Vessel Lost in the Java Sea [The University of Leeds]. http:/ / etheses.whiterose.ac.uk/6912/1/SirenOfCirebonFinal.pdf

Mahdi, W. (1999). The dispersal of Austronesian boat forms in the Indian Ocean. In R. Blench \& M. Spriggs (Eds.), Archaeology and Language III: Artefacts, languanges and texts (pp. 144-179). London \& New York: Routledge. http://www.academia.edu/download/35025241/Mahdi_1WrldArchaeo34 _1999.pdf

Manguin, P.-Y. (2009). The Boat Remains of Punjulharjo: A preliminary report.

Manguin, P.-Y. (2016). Austronesian shipping in the Indian Ocean: from outrigger boats to trading ships. In G. Campbell (Ed.), Early Exchange Between Africa and the Wider Indian Ocean World (pp. 51-76). Cham: Springer. https://link.springer.com/chapter/10.1007/978-3-319-33822-4_3

Mochtar, A. S. (2018). The Seventh-Century Punjulharjo Boat from Indonesia: A study 
of the early Southeast Asian lashed-lug boatbuilding tradition. Flinders University.

Natural England. (2008). Preparing a Heritage Management Plan.

Perring, D. (2008). Introducing the Center for Applied Archaeology. Archaeology International, 11, 19-22. https://doi.org/http://doi.org/10.5334/ai.1107

Septyana, N. H. (2012). Sejarah perkembangan klenteng Gie Yong Bio di Lasem dan pengaruhnya masyarakat 1967-1998. Journal of Indonesian History, 1(2), 100-109. https://journal.unnes.ac.id/sju/index.php/jih/article/download/2233/20 49

Rencana Strategis Sekretaris Kabinet 2015-2019, Pub. L. No. PERSETKAB No.7 (2016).

Sulistyarto, P. H. (2013). Teknologi pembuatan perahu kuno Punjulharjo. In I. Adrisijanti (Ed.), Perahu Nusantara (pp. 75-94). Yogyakarta: Kepel Press.

UNESCO, ICCROM, ICOMOS, \& IUCN. (2013). Managing Cultural World Heritage. UNESCO World Heritage Center. 